\title{
Penguatan Peran Faith Based Organizations (FBO) dalam Pencegahan dan Penanggulangan HIV dan AIDS melalui Peran Aktif Young Relegiuos Leader di Tretes Prigen Pasuruan
}

\author{
Nyoko Adi Kusworo', Zainul Ahwan ${ }^{2}$, Mukhid Mashuri ${ }^{1}$, Mochamad Hasyim ${ }^{1}$ \\ ${ }^{1}$ Fakultas Agama Islam Universitas Yudharta Pasuruan \\ ${ }^{2}$ Fakultas Ilmu Sosial Ilmu Politik Universitas Yudharta Pasuruan \\ nyoko@yudharta.ac.id, zezen@yudharta.ac.id, mukhid@yudharta.ac.id, hasyim@yudharta.ac.id
}

\begin{abstract}
Official data from the National AIDS Commission (KPA) showed that East Java ranks 2 (two) for most HIV. Whereas Pasuruan Regency was ranked as number 2 (two) the most cases of HIV and AIDS from all Regencies in East Java with 984 cases starting from 2000-2016. The majority of HIV cases were dominated by productive age (adolescents) between the ages of 20-29 years, the number of which reached around 300 people or around 32\%. of the total HIV cases in Pasuruan Regency (KPA data of Pasuruan from 2000-2016). While in terms of data on HIV distribution by region, Prigen Subdistrict was ranked first with 82 cases. Responding to the issue, the role of the Faith Based Organization (FBO) was based on youth through the active role of Young Relegious Leader in Prigen Pasuruan was very encouraged to participate in HIV \& AIDS prevention especially in adolescents. To support and strengthen the role of FBO in prevention of HIV and AIDS through efforts: to increase capacity building and knowledge of young religious leader on HIV and AIDS in medical and religion perspective, strengthening communication skills in social campaigns through the use of video blog media (VLOG), making HIV (AIDS) prevention materials (Modules) and building related partnership networks. The institutional strengthening of FBO was focused on Youth-Based FBO in Prigen Pasuruan which included Nabdlatul Ulama' (IPNU \& IPPNU) Student Association, Mubammadiyah Youth Association (IPM) and representatives from Christian Youth in Prigen Pasuruan. Through strengthening this role, it was expected that the FBO would be able to prevent HIV/AIDS in members/congregations in their respective organizations in planned and independent manner. In addition, strengthening the role of FBO would also be a new movement of FBO in Tretes Prigen area in taking responsibility for HIV and Narcotics issues in adolescents.
\end{abstract}

Keyword: Faith Based Organizations, HIV and AIDS, Young Releginos Leader, Pasuruan

\section{Pendahuluan}

Human Immunodeficiency Virus (HIV) merupakan penyebab penyakit Acquired Immunodeficiency Syndrome (AIDS) dengan cara menyerang sel darah putih sehingga dapat merusak sistem kekebalan tubuh manusia. Kasus HIV \&AIDS merupakan fenomena gunung es, dimana jumlah kasus yang ditemukan / dilaporkan jauh lebih sedikit dibandingkan dengan yang sebenarnya. Data jumlah kasus HIV dan AIDS yang dilaporkan setiap tahunnya sangat meningkat secara signifikan. Di seluruh dunia, setiap hari diperkirakan sekitar 2000 anak dibawah 15 tahun tertular HIV dan sekitar 1400 anak di bawah usia 15 tahun meninggal dunia, serta menginfeksi lebih dari 6000 orang berusia

Volume 2, Number 2, November 2018| 137

Penguatan Peran Faith Based Organizations (FBO) Dalam Pencegahan dan Penanggulangan HIV dan AIDS Melalui Peran Aktif Young Relegiuos Leader di Tretes Prigen Pasuruan 


\section{ENGAGEMENT}

Gurnal Pengabdian Kepada Masyarakat

ISSN : 2579-8375 (Print)

ISSN : 2579-8391 (Online)

produktif. ${ }^{1}$ Persopalan HIV dan AIDS merupakan permasalahan universal yang sudah menjadi permasalahan sistemik yang masuk keberbagai sistem kehidupan sosial baik kesehatan, ekonomi sosial dan budaya. Maka dari itu, HIV bukan hanya dipandang sebagai permasalahan kesehatan semata tetapi HIV dan AIDS sudah dipandang sebagai ancaman terhadap keberlanjutan proses peradaban suatu masyarakat karena HIV tidak hanya mengancam anggota-anggota keluarga tetapi juga dapat memutus kelangsungan suatu keluarga dalam suatu masyarakat. Karena itu, penanggulangan HIV dan AIDS menjadi sesuatu yang urgen dan fital dalam rangka menjaga hakhak dasar masyarakat atas derajad kesehatan dan proses kelangsungan peradaban.

Angka HIV dan AIDS di Kabupaten Pasuruan menurut data dari Komisi Penanggulangan AIDS (KPA) Kabupaten Pasuruan, jumlah kasus HIV di Indonesia sudah mencapai 142.950 dan AIDS mencapai 55.623. Sedangkan menurut data peringkat kasus HIV terbanyak, DKI Jakarta berada diurutan pertama dengan jumlah kasus 31.586 disusul Jawa Timur diurutan ke-2 (dua) dengan jumlah kasus 31.131, di urutan ke-3 (tiga) ditempati Papua dengan jumlah 15.686 selanjutnya Jawa Barat dengan jumlah kasus 12.084 dan Bali dengan jumlah kasus 9.051. Sedangkan Kasus HIV dan AIDS di Kabupaten Pasuruan tercatat sebanyak 984 kasus HIV dan 518 AIDS. Dimana penyebaran HIV didominasi oleh usia produktif / remaja (20-29 tahun) sebanyak $32 \%$ dari total kasus HIV di Kabupaten Pasuruan dengan jumlah 345 kasus $^{2}$

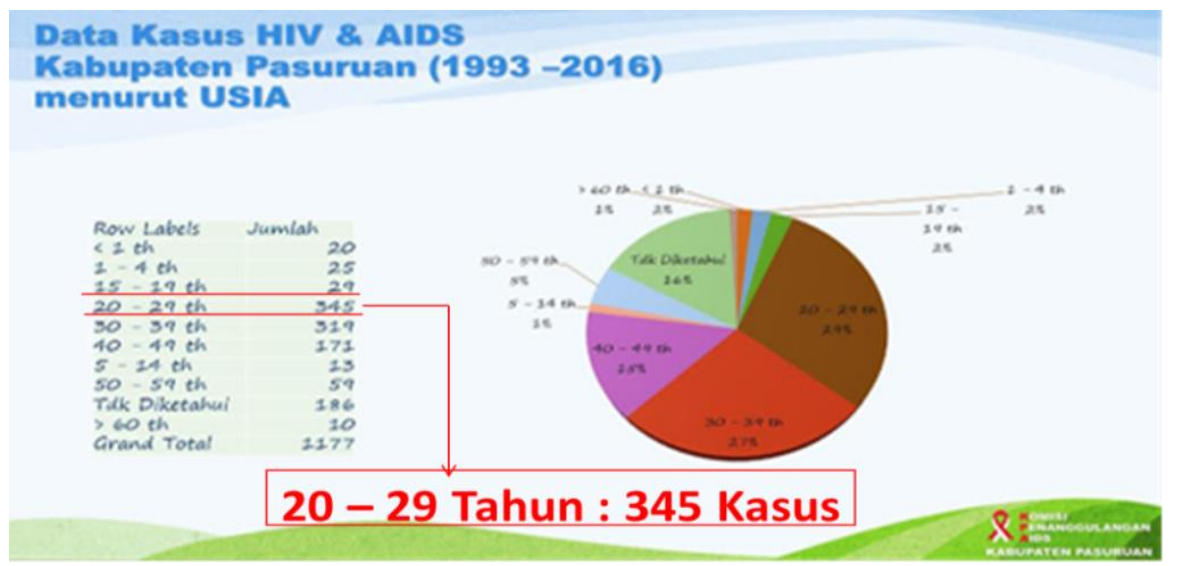

Gambar 1. Prosentase data kasus HIV dan AIDS menurut usia

Masa remaja (adolescent) merupakan periode yang kritis pada perkembangan manusia baik secara fisiologis, psikologis dan sosial sehingga cenderung labil dan imitatif dan kurang berfikir secara matang dan jangka panjang. Kondisi inilah kemudian majadi salah satu faktor penyebab

${ }^{1}$ Lenny Octavianty et al., "Pengetahuan, Sikap Dan Pencegahan HIV/AIDS Pada Ibu Rumah Tangga," Jurnal kesehatan masyarakat 11, no. 1 (2015): 53-58.

${ }^{2}$ Komisi Penanggulangan AIDS [KPA] Kabupaten Pasuruan, "Data Kasus HIV Dan AIDS Di Kabupaten Pasuruan,” last modified 2014, http://kpakabpasuruan.blogspot.com/p/data-kasus-hiv-aids.html. 


\section{ENGAGEMENT}

Gurnal Pengabdian Kepada Masyarakat

ISSN : 2579-8375 (Print)

ISSN : 2579-8391 (Online)

tingginya berbagai kasus remaja yeng terjadi termasuk dalam persoalan HIV dan Aids. ${ }^{3}$ Data tingginya kasus HIV pada remaja di Kabupaten Pasuruan sangat relevan dengan temuan data Komisi Perlindungan Anak Indonesia (KPAI) dalam Dadang R, (2018) diketahui sebanyak 32\% remaja usia 14 hingga 18 tahun di kota besar di Indonesia (Jakarta, Surabaya, dan Bandung) pernah berhubungan seksual pranikah dan membuktikan 62,7\% remaja kehilangan perawan saat masih duduk di bangku SMP, bahkan 21,2\% diantaranya ekstrim, yakni pernah melakukan aborsi. Tingginya penggunaan napza suntik dan aktifitas seksual pada remaja disinyalir sebagai prediktor transmisi virus HIV pada generasi muda tersebut. ${ }^{4}$

Sedangkan dari sisi data HIV di Kabupaten Pasuruan berdasarkan wilayah, Kecamatan Prigen masih menduduki peringkat pertama sebagai wilayah terbanyak kasus HIV di Kabupaten Pasuruan dengan jumlah mencapai 95 kasus. Peringkat selanjutnya diikuti Kecamatan Pandaan yang mencapai 85 kasus. $^{5}$

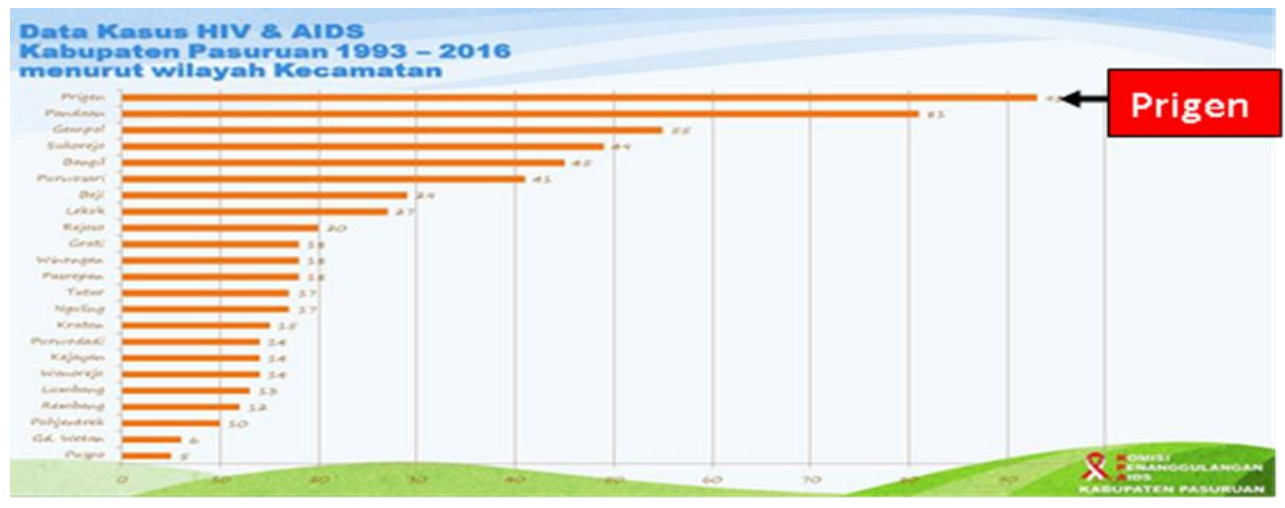

\section{Gambar 2. Prosentase data kasus HIV dan AIDS berdasarkan wilayah}

Tingginya kasus HIV di Prigen diindikasi karena dampak dari adanya tempat wisata yang dikenal dengan "kawasan tretes". Kawasan Tretes merupakan suatu wilayah yang terdiri dari banyak bangunan vila dan hotel. Trates merupakan destinasi wisata yang sangat familiar dengan wisata hiburan malam dan prostitusi. Bisa dikatakan sebagai tempat lokalisasi prostitusi yang ada di Kabupaten Pasuruan. Berbagai pemberitaan soal Tretes yang mengulas seputar praktik prostitusi sangat mudah dijumpai diberbagai media ${ }^{6}$. Seperti dibawah ini:

${ }^{3}$ Sudikno Sudikno, Bona Simanungkalit, and Siswanto Siswanto, "Pengetahuan HIV Dan AIDS Pada Remaja Di Indonesia (Analisis Data Riskesdas 2010)," Jurnal Kesehatan Reproduksi 1, no. 3 Agt (2011): 145-154.

${ }^{4}$ Dadang Purnama and W Witdiawati, "Literasi Penyakit HIV-AIDS Pada Siswa Madrasah Tsanawiah Negeri 1 Garut," Media Karya Kesehatan 1, no. 1 (2018).

5 "Data Kecamatan Prigen Kabupaten Pasuruan.," WIKIPEDIA, http://id.wikipedia.org/wiki/Prigen,_Pasuruan.

6 “Empat PSK Tretes Kembali Ditemukan Positif HIV," News.Detik.Com, last modified 2017, https:// news.detik.com/berita-jawa-timur/d-3503867/empat-psk-tretes-kembali-ditemukan-positif-hivaid.

Volume 2, Number 2, November 2018| 139 Penguatan Peran Faith Based Organizations (FBO) Dalam Pencegahan dan Penanggulangan HIV dan AIDS Melalui Peran Aktif Young Relegiuos Leader di Tretes Prigen Pasuruan 


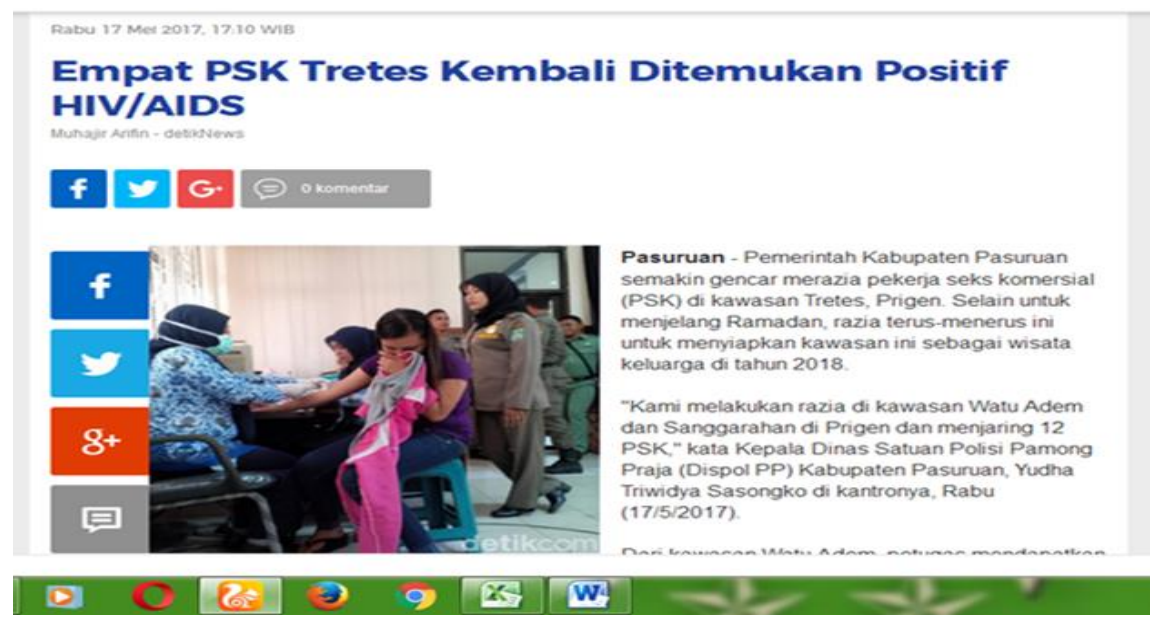

Gambar 3. Berita empat PSK Tretes positif HIV

Kawasan lokalisasi (Tretes) sebagai tempat lokalisasi terbesar kedua di Jawa Timur disaat lokalisasi Dolly ketika masih beroperasi. Selain itu Kabupaten Pasuruan juga merupakan daerah industri (dengan kurang lebih 5000 industri sekala sedang dan besar) serta sebagai kawasan pariwisata yang sangat memungkinkan terjadinya migrasi HIV dari satu tempat ketempat lain sebagaimana hasil penelitian yang dilakukan oleh KPAD. ${ }^{7}$ Dalam upaya melakukan pencegahan dan penanggulangan terhadap bahaya HIV dan AIDS khusnya pada target sasaran generasi muda dengan menggunakan pendekatan pelibatan FBO berbasis kepemudaan ini mengingat jumlah penderita HIV di Kabupaten Pasuruan paling banyak didominasi oleh generasi remaja. Secara psikososial tahap tumbuh kembang anak remaja memang selalu berkeinginan untuk mencoba sesuatu yang baru, mencari identitas diri dan uji nyali. ${ }^{8}$ Pelibatan FBO berbasis kepemudaan menjadi sangat relevan karena memiliki kesamaan karakter satu sama lain sehingga upaya pencegahan bahaya HIV bisa berjalan dengan baik dan efektif.

Pada persoalan ini Tim PKM Universitas Yudharta Pasuruan telah melakukan upaya nyata dengan 10 lembaga keagamaan berbasis kepemudaan di Kecamatan Prigen Kabupaten Pasuruan untuk melakukan pencegahan dan penanggulangan menyebarnya HIV dan AIDS dengan merumuskan strategic plan dimasing-masing lembaga agama dan diaplikasikannya. Selain itu, Tim PKM Universitas Yudharta Pasuruan juga melakukan kerjasama dengan lembaga NGO lokal yang berkonsentrasi pada isu HIV dan AIDS untuk bersama-sama dengan lembaga agama dan lembaga

7 Ibid.

${ }^{8}$ Elly Nurachmah, "Faktor Pencegahan Hiv/Aids Akibat Perilaku Berisiko Tertular Pada Siswa SLTP," Makara Seri Kesehatan 13, no. 2 (2009): 63-68.

Volume 2, Number 2, November 2018| 140 Penguatan Peran Faith Based Organizations (FBO) Dalam Pencegahan dan Penanggulangan HIV dan AIDS Melalui Peran Aktif Young Relegiuos Leader di Tretes Prigen Pasuruan 


\section{ENGAGEMENT}

Gurnal Pengabdian Kepada Masyarakat

ISSN : 2579-8375 (Print)

ISSN : 2579-8391 (Online)

pendidikan untuk mendorong pemerintah daerah mengambil tindakan nyata dalam nensukseskan tujuan bersama melakukan pencegahan dan penanggulangan HIV dan AIDS di daerah.

Tim PKM Universitas Yudharta Pasuruan meyakini bahwa sinergi dan peran nyata lembaga keagamaan, pemerintah, swasta dan lembaga pendidikan menjadi kunci keberhasilan bagi program ini. Dengan adanya dorongan dari semua pihak. Komitmen pemerintah Kabupaten Pasuruan pada persoalan HIV telah diwujudkan dalam Perda Nomor 4 Tahun 2010 tentang Penanggulangan HIV dan AIDS yang menekankan pada pentingnya semua elemen masyarakat untuk mendukung tercapaianya tujuan Nasional dan Daerah dalam melakukan pencegahan dan penanggulangan HIV dan AIDS. Pada bab III bagian kesatu soal pelaku pada pasal 5 ayat 1 dijelaskan bahwa penanggulangan HIV dan AIDS diselenggarakan oleh semua masyarakat, pemerintah daerah serta sektor terkait lainnya berdasarkan kemitraan. Pada pasal 2 menyebutkan masyarakat merupakan pelaku utama dalam melakukan pencegahan HIV dan AIDS dan pada pasal 3 menyebutkan bahwa pemerintah daerah harus ikut terlibat dalam melaksanakan, mengarahkan, dan membimbing dan menciptakan suasana yang mendukung penanggulangan HIV dan AIDS di daerah. ${ }^{9}$ Selain itu, pada tahun 2018 ini pada masa kepemerintahan periode ke-2 Bupati Irsyad Yusuf persoalan HIV dan AIDS menjadi salah satu program prioritas yang akan dilaksanakan pada masa pemerintahannya.

\section{Metode}

Kegiatan pengabdian masyarakat tentang Penguatan Peran Lembaga Sekolah dalam Pencegahan dan Penanggulangan HIV dan AIDS Pada Siswa SLTA dikawasan Tretes Prigen Pasuruan Melalui Student Learning Center (SLC) menggunakan pendekatan metode Participatory Action Research (PAR) dan pengorganisasian masyarakat Community Organizer (CO). Pendekatan Participatory Action Research (PAR) ${ }^{10}$ dilakukan untuk mendapatkan data awal yang dibutuhkan dalam program PKM ini dengan melibatkan secara aktif semua pihak-pihak stakeholders baik itu lembaga pendidikan SLTA di kawasan Prigen, Dinas Kesehatan, Komisi Penanggulangan AIDS (KPA) Kabupaten Pasuruan, NGO serta Perguruan Tinggi. Pendekatan PAR ini dibutuhkan untuk mengkaji tindakan/kegiatan pencegahan HIV dan AIDS disekolah guna memperoleh data primer terkait kegiatan yang sedang atau telah berlangsung dalam rangka melakukan perubahan ke arah yang lebih baik dengan mempertimbangkan berbagai fakta lapangan yang telah diproleh oleh tim

\footnotetext{
${ }^{9}$ Bupati Pasuruan, Peraturan Daerab Kabupaten Pasuruan Nomor 4 Tabun 2010 Tentang Tentang Penanggulangan HIV Dan AIDS (Indonesia, 2010).

${ }^{10}$ Agus Afandi, Mohammad Hadi Sucipto, and Abdul Muhid, Modul Participatory Action Research (PAR) Untuke Pengorganisasian Masyarakat (Community Organizing) (Lembaga Penelitian dan Pengabdian kepada Masyarakat, UIN Sunan Ampel Surabaya, 2016). 91.
}

Volume 2, Number 2, November 2018 | 141 Penguatan Peran Faith Based Organizations (FBO) Dalam Pencegahan dan Penanggulangan HIV dan AIDS Melalui Peran Aktif Young Relegiuos Leader di Tretes Prigen Pasuruan 


\section{ENGAGEMENT}

Jurnal Pengabdian Kepada Masyarakat

ISSN : 2579-8375 (Print)

ISSN : 2579-8391 (Online)

PKM Universitas Yudharta Pasuruan.

Pada tahapan implementasi program pengabdian dilakukan dengan pendekatan Community Organizer (CO). Menurut Beckwith \& Cristina Lopez (1997), yang dikutip oleh Wicaksono \& Darusman, Pengertian Pengorganisasian Masyarakat dapat didefinisikan sebagai :"Proses membangun kekuatan dengan melibatkan konstituen sebanyak mungkin melalui proses menemukenali ancaman yang ada secara bersama-sama, menemu-kenali penyelesaian-penyelesaian yang diinginkan terhadap ancaman-ancaman yang ada; menemu-kenali orang dan struktur, birokrasi, perangkat yang ada agar proses penyelesaian yang dipilih menjadi mungkin dilakukan, menyusun sasaran yang harus dicapai; dan membangun sebuah institusi yang secara demokratis diawasi oleh seluruh konstituen sehingga mampu mengembangkan kapasitas untuk menangani ancaman dan menampung semua keinginan dan kekuatan konstituen yang ada." 11

Pengorganisasian masyarakat disini dimengerti sebagai suatu proses pembangunan kekuatan yang melibatkan berbagai pihak dalam menggali persoalan yang terjadi di masyarakat dengan potensi-potensi yang ada dan melakukan intervensi agar terjadi perubahan kearah yang lebihbaik. Ada tiga hal yang terkait dalam pengertian pengorganisasian masyarakat ini, yakni (1) ada persoalan dan potensi untuk penyelesaian masalah, (2) intervensi kearah perubahan, dan (3) pihak yang terkait dalam intervensi masyarakat. Secara detail metode/teknis langkah-langkah dalam pelaksanaan kegiatan pengabdian masyarakat sebagaimana berikut:

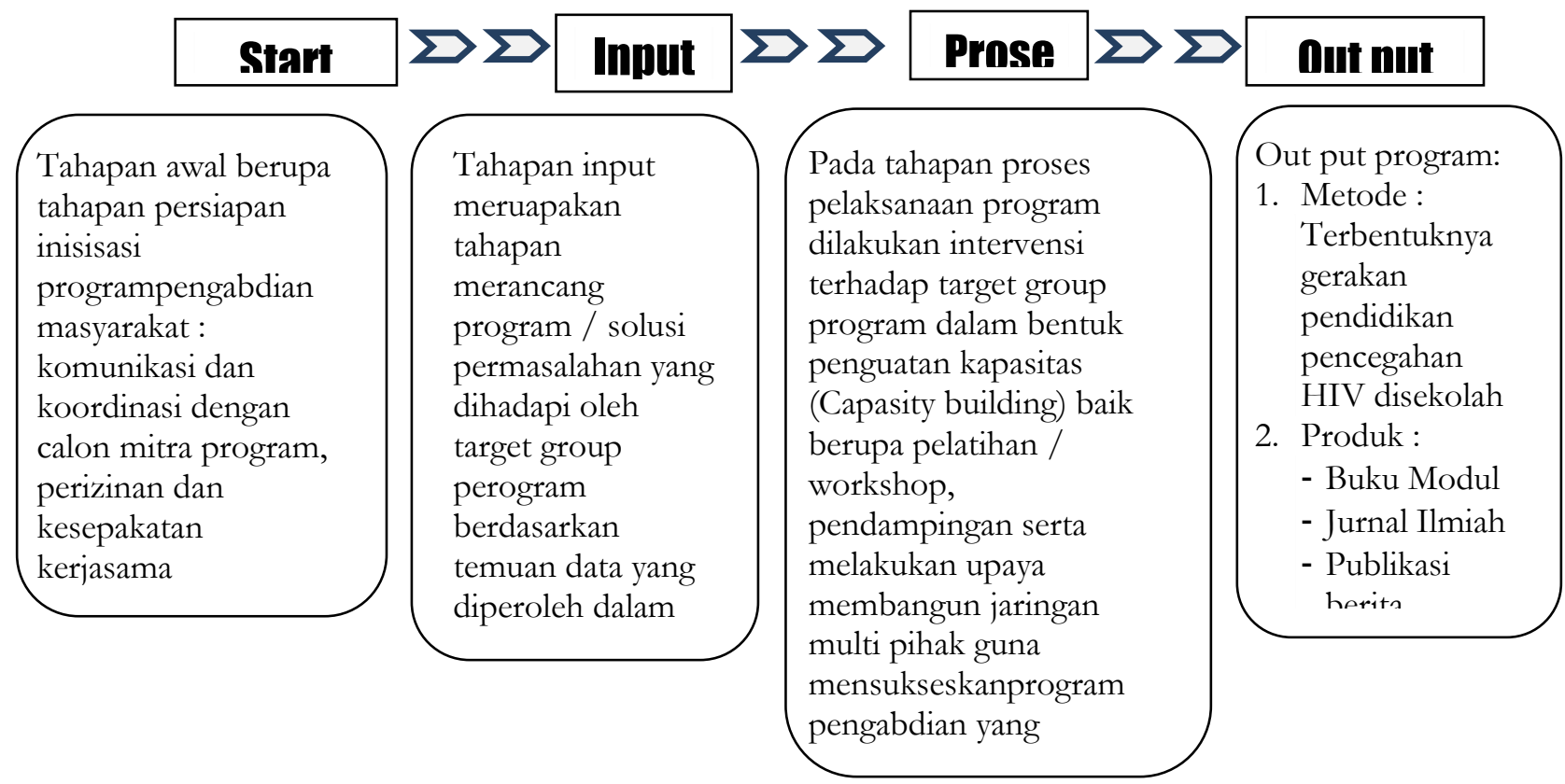

11 Wazir Wicaksono and Taryono Darusman, Pengalaman Belajar Praktek Pengorganisasian Masyarakat Di Simpul Belajar (Bogor: Yayasan Putera, 2001). 


\section{ENGAGEMENT}

Jurnal Pengabdian Kepada Masyarakat

ISSN : 2579-8375 (Print)

ISSN : 2579-8391 (Online)
This work is licensed under a Creative Commons Attribution-ShareAlike 4.0 International License.

\section{Gambar 4. Diagram Metode Pelaksanaan Program}

Dalam kaitannya dengan permasalahan HIV dan AIDS yang didominasi oleh usia produktif dengan menempatkan kecamatan Prigen sebagai kecamatan dengan peringkat kasus HIV terbanyak di Kabupaten Pasuruan, maka target group para aktifis/tokoh muda agama yang berada di Kec. Prigen adalah sebuah pilihan yang realistis dan sangat relevan. Upaya suksesi program yang dilakukan dengan merumuskan beberapa strategi pendekatan komunitas. Pertama, pendekatan personal (Personal approach) pendekatan ini diorentasikan untuk memberikan pemahaman kepada tokoh kunci (Key person) agar mendukung program yang akan dilaksanakan. Kedua, menggunakan pendekatan komunitas (community approach) Tim Universitas Yudharta Pasuruan melakukan kerjasama dengan komunitas anta rumat beragama berbasis kepemudaan di kawasan Prigen Pasuruan. Ketiga, Tim PKM Universitas Yudharta Pasuruan melakukan kerjasama dengan lembaga pemerintah terkait dalam hal ini adalah Dinas Kesehatan (DINKES) dan Komisi Penanggulangan AIDS Daerah (KPAD) Kabupaten Pasuruan.

Upaya peningkatan peran FBO dalam pencegahan bahaya HIV dan AIDS dilakukan dengan peningkatan kapasitas (capacity building) young relegious leader dalam hal pengetahuan seputar HIV dan AIDS baik dalam tinjauan medis maupun agama, selain itu juga dilakukan upaya penguatan skill komunikasi dalam melakukan kampanye HIV baik dalam bentuk sosialisasi maupun kampanye inovatif dengan memanfaatkan media video blog (Vlog). Selain itu, untuk mendukung kelancaran program pencegahan HIV dan AIDS yang akan dilakukan oleh para aktivis muda agama juga dibekali dengan modul pencegahan HIV dan AIDS serta penguatan jaringan. Program ini dilaksanakan dalam kurun waktu 5 bulan efektif mulai bulan Juli-November 2018.

\section{Hasil dan Diskusi}

\section{Penyajian Data program PKM}

\section{Worksop Pencegahan HIV dan AIDS untuk FBO}

Workshop ini dilakukan pada 12 Agustus 2018 di Universitas Yudharta Pasuruan yang melibatkan 36 peserta dari 10 orgasisasi keagamaan berbasis kepemudaan di Kec. Prigen Kabupaten Pasuruan yaitu IPNU dan IPPNU dari Pengurus anak cabang (PAC) Prigen dan Pengurus Ranting se Kec. Prigen, IPM serta pemuda Kristen di Kec. Prigen. Workshop ini menghadirkan narasumber dari Komisi Penanggulangan Aids (KPA) Kabupaten Pasuruan yaitu dr.Rahmat Aprillah D. S, Ked Yang menyampaikan tentang data kasus HIV di Kabupaten Pasuruan serta fenomena HIV di Kec. Prigen yang pada tahun 2017 menjadi kecamatan dengan tingkat HIV tertinggi di Kab, Pasuruan. Dari pemaparan data tersebut kemudian dijadikan sebagai 


\section{ENGAGEMENT}

Jurnal Pengabdian Kepada Masyarakat

ISSN : 2579-8375 (Print)

ISSN : 2579-8391 (Online)

bahan diskusi workshop untuk mencari strategi pencegahan HIV dan AIDS di Kec. Prigen dengan melibatkan para aktifis muda organisasi keagamaan. hasil nyata kegaitan workshop ini telah menyadarkan para tokoh muda agama untuk tergerak dalam turut serta melakukan kegiatan pencegahan HIV di daerahnya, selain itu, melalui Pimpinan Anak Cabang (PAC) IPNU \& IPPNU akan membuat perencanaan program pencegahan HIV dan AIDS yang akan dilakukan dalam setiap kegiatan IPNU \& IPPNU sampai pada level ranting di Kec. Prigen.

\section{Training Capacity Building for $F B O$}

Training untuk para tokoh muda agama ini dilaksanakan pada tanggal 19 Agustus 2018. Kegiatan training ini dilaksanakan di Universitas Yudharta Pasuruan. Dalam kegiatan ini melibatkan 33 peserta dari perwakilan organisasi IPNU/IPPNU, IPM serta pemuda Kristen yang berbeda di Kec. Prigen serta Komisi Penanggulanagn AIDS Daerah (KPAD). Dalam training ini peserta yang terdiri para aktifis muda agama dididik bagaimana mempunyai kemampuan dalam menyampaikan materi HIV dan AIDS pada anggota / jama'ahnya dengan efektif dan menarik, dibekali pengetahuan soal HIV dan AIDS secara medis dan agama, penggunaan metodologi partisipatoris, mengetahui mitos-mitos yang terjadi seputar masalah HIV dan AIDS, macammacam stigma dan diskriminasi yang sering terjadi dimasyarakat pada isu HIV dan AIDS serta mengetahui kaitannya diskriminasi dengan pelanggaran HAM. Hasil nyata kegiatan ini secara Kognitif menunjukkan adanya perubahan yang signifikan pada aktivis FBO telah mampu memahami HIV dan AIDS dalam konteks medis dan agama. Secra afektif para aktivis FBO mulai menyadari bahwa orang dengan HIV dan AIDS (ODHA) merupakan korban dari ketidak tahuannya tentang HIV, perlunya pendampingan/tuntutan rohani (bertobat) agar mereka yakin bahwa tobatnya diterima serta menghindari sikap stigma dan diskriminasi pada ODHA. Secara Psikomotorik, para aktivis muda FBO mulai memerankan peranan sebagai bagaian dari gerakan pencegahan HIV dan AIDS mulai dari struktur PAC sampai pada struktur ranting di Kec. Prigen untuk sama-sama melakukan proteksi HIV pada anggotanya masing-masing.

\section{Training Inovative Campign melalui Video Blog (Vlog)}

Sebagai bentuk respon terhadap perkembangan teknologi, kemampuan melakukan kegiatan kampanye HIV secara inovatif dalam bentuk video blog menjadi kebutuhan yang harus dikuasai guna mendukung kesuksesan program kampanye pencegahan bahaya HIV dan AIDS di Kabupaten Pasuruan. Untuk itu dalam kegiatan ini para aktifis muda agama dibekali dengan skill pemanfaatan video blog sebagai media kampanye. Kegiatan ini dilaksanakan di Sekolah Alam Alas 


\section{ENGAGEMENT}

Gurnal Pengabdian Kepada Masyarakat

ISSN : 2579-8375 (Print)

ISSN : 2579-8391 (Online)

Welirang Prigen dengan melibatkan 25 peserta dari perwakilan IPNU/IPPNU se-kecamatan Prigen dengan menghadirkan narasumber Azharus Syarif alumni Ilmu Komunikasi Universitas Yudharta Pasuruan. Dalam pelatihan ini peserta dibekali tentang tahapan-tahapan pembuatan video blog mulai dari membuat story line, pembuatan story board, pengambilan gambar video serta editing video. Hasil nyata kegiatan ini telah meningkatkan pengetahuan dan skill para aktivis muda FBO dalam memanfaatkan perkembangan teknologi untuk digunakan sebagai media kampanye pencegahan bahaya HIV dan AIDS di daerahnya. Pasca kegiatan ini mitra program telah mengerti dan mampu bagaimana melakukan tahapan-tahapan dalam membuat video mulai dari bagaimana mencari ide cerita, menulis story line, membuat story board, pengambilan gambar sampai pada tahapan editing video.

\section{Modul Pencegahan HIV dan AIDS}

Guna mendukung kesuksesan program dan mengingatkan kesadaran pada masyarakat tentang bahaya HIV dan AIDS serta kaitannya dengan kampanye anti stigma dan diskriminsai pada PLHIV, tim PKM Universitas Yudharta Pasuruan mencetak stiker kampanye bahaya HIV dan AIDS yang dibagikan pada mitra program serta masyarakat, selain itu juga dilakukan pembuatan modul pencegahan HIV dan AIDS yang nantinya bisa digunakan sebagai acuan para aktifis/tokoh muda agama dalam melakukan kegiatan pencegahan dan penganggulangan bahaya HIV dan AIDS di Kec. Prigen Khususnya dan masyarakat Pasuruan pada umumnya.

\section{Pembahasan}

\section{Isu-Isu yang berkembang di masyarakat tentang HIV \& AIDS}

Pada saat kegiatan program yaitu workshop pencegahan HIV dan AIDS untuk aktivis/tokoh muda FBO yang dilakukan di Universitas Yudharta Pasuruan masih dijumpai banyak para tokoh muda FBO seperti pengurus IPNU, IPPNU, IPM dan pemuda Kristen di Kec. Prigen yang belum memahami persoalan HIV secara komprehensip dan tepat sehingga memunculkan anggapan bahwa HIV semata-mata menimpa pada orang yang tidak menjalankan agama dengan baik serta mendapatkan laknat dari Tuhan. Disisi lain secara umum masyarakat masih menganggap bahwa istilah HIV dan AIDS biasanya tergambar sebagai masalah medis yang timbul akibat suatu perilaku negatif dalam pergaulannya. Penderitanya yang di sebut ODHA (Orang Dengan HIV/AIDS) sering dijauhi dalam pergaulan karena dianggap perilaku negatifnya dapat menimbulkan HIV dan AIDS. Data temuan program dalam wokshop pencegahan HIV dan AIDS yang dilakukan di Universitas Yudharta Pasuruan menyimpulkan bahwa kondisi ini terjadi karena masih lemahnya 


\section{ENGAGEMENT}

Gurnal Pengabdian Kepada Masyarakat

ISSN : 2579-8375 (Print)

ISSN : 2579-8391 (Online)

pengetahuan masyarakat tentang HIV dan AIDS khususnya dalam tinjauan medis. Banyak masyarakat masih menganggap penularan HIV dapat terjadi dengan mudah. Isu yang berkembang di masyarakat mengenai penularan HIV antara lain bahwa penularan HIV dapat terjadi melalui kontak sosial seperti bersalaman, berpelukan, atau berciuman dengan penderita HIV dan AIDS, memakai fasilitas umum bersama-sama dengan penderita HIV dan AIDS seperti toilet, kolam renang serta berbagi makanan atau menggunakan alat makan secara bersama dengan ODHA. Pemahaman yang salah ini menjadi isu yang berkembang pada masyarat mengenai penularan HIV sehingga menimbulkan suatu opini bahwa HIV itu adalah virus mematikan yang dapat menular dengan mudahnya kapanpun, dimanapun, dan kepada siapapun.

Selain itu persoalan ini juga diperparah dengan munculnya stigma HIV di masyarakat yang melabeli para korban HIV semata-mata sebagai akibat dari perbuatan yang dilarang oleh agama. Sayangnya peranan aktivis muda FBO baik IPNU \& IPPNU, IPM di Kec. Prigen sejauh ini masih belum terlibat secara aktif dalam program pencegahan HIV di daerahnya. Program-program yang dijalankan lebih fokus pada program kaderisasi dan ideologisasi organisasi serta program-program pendidikan. Disisi lain memang ditemukan data bahwa para aktivis muda FBO masih belum memiliki pengetahuan yang cukup tentang HIV dan AIDS dalam tinjaun medis serta agama secara tepat sehingga tidak bisa melakukan kegiatan pencegahan HIV dan AIDS di daerahnya masingmasing.

Upaya untuk memperkuat peranan FBO dalam pencegahan dan penanggulangan bahaya HIV dan AIDS khususnya pada generasi muda dilakukan dengan meningkatkan kesadaran, pengatahuan serta skill dalam pencegahan HIV dan AIDS melalui berbagai kegiatan pelatihan/workshop. Program penguatan peran Faith Based Organizations (FBO) dalam pencegahan dan penanggulangan HIV dan AIDS melalui peran aktif young releginos leader di Tretes Prigen Pasuruan ini menjadi langkah taktis-strategis dalam membendung persoalan HIV di Kec. Prigen pada khususnya dan Pasuruan pada umumnya. Program ini telah mampu meningkatkan kesadaran dan kepedulian, meningkatkan pengetahuan dan skill para tokoh muda FBO untuk tergerak dalam turut serta melakukan kegiatan pencegahan HIV di daerahnya, selain itu, melalui Pimpinan Anak Cabang (PAC) IPNU \& IPPNU akan membuat perencanaan program pencegahan HIV dan AIDS yang akan dilakukan dalam setiap kegiatan IPNU \& IPPNU sampai pada level ranting di Kec. Prigen. Keterlibatan aktifis muda FBO akan mampu merubah persepsi yang salah dimasyarakat terkait HIV baik dalam ranah medis maupun stigma HIV yang ditimbulkan dari mitos-mitos, pemahaman agama yang kurang tepat di masyarakat. Problem ini menjadikan peranan FBO menjadi fital dan strategis dalam merupah polapikir, sikap dan perilaku masyarakat di Pasuruan 
terhadap persoalan HIV dan AIDS. ${ }^{12}$

Penyampaian pesan-pesan agama dalam pencegahan HIV dan AIDS akan menjadi sangat efektif apabila dilakukan oleh para pemuka agama. Pemuka agama merupakan sosok panutan yang mempunyai kredibilitas dan integritas yang bisa diikuti anggota/jama'ahnya bahka pada masyarakat secara luas. ${ }^{13}$ Melihat hal itu, peranan dan posisi FBO sebagai ujung tombak pencegahan HIV dan AIDS di kawasan Tretes Prigen Pasuruan menjadi sangat tepat mengingat masyarakat Pasuruan pada umumnya memiliki budaya paternalistik yang cukup tinggi. FBO dengan para tokoh agamanya menjadi referensi masyarakat dalam menentukan tindakannya sehingga peningkatan peran dan kapasitas pengetahuan serta skill FBO pada persoalan HIV dan AIDS akan menjadi rujukan masyarakat dalam menentukan sikap.

\section{Persoalan HIV dan Stigma HIV di masyarakat}

Pencegahan dan penanggulangan HIV dan AIDS harus dilakukan secara komprehensif. Baik itu pada permasalahan stigma dan diskriminasi juga menjadi permasalahan penting yang harus diselesaikan dalam melakukan pencegahan dan penanggulangan terhadap penyebaran HIV dan AIDS. Stigma dan diskriminasi pada kasus HIV dan AIDS yang muncul di Kabupaten Pasuruan sebagaimana data yang diperoleh dalam workshop antar FBO yang telah dilakukan di Universitas Yudharta Pasuruan diawal program ditemukan dua problem mendasar yaitu: Pertama, tingkat pengetahuan FBO serta masyarakat yang masih awam terhadap HIV dan AIDS. Kedua, adalah memahami persoalan HIV dan AIDS dalam pandangan agama yang parsial.

Dalam konteks pemahaman HIV dalam tinjauan medis para aktifis muda FBO telah dibekali pengetahuan melalui pelatihan yang telah dilaksanakan oleh tim PKM Universitas Yudharta Pasuruan sehingga sudah ada perubahan/peningkatan pengetahuan tentang HIV dan AIDS dimana sudah tidak lagi ada perasaan was-was dan menjauhi ODHA dalam pergaulan sosial serta mulai muncul rasa kepeduliannya terhadap para korban HIV. Perubahan pengetahuan dan sikap ini secara mendasar sebagai indikasi dampak dari adanya pemahaman yang benar dalam memahami persolan HIV dan Aids. Aktifis muda FBO telah medapatkan pemahaman yang jelas mulai dari apa itu HIV dan AIDS, bagimana HIV dan AIDS bisa ditularkan, melalui media apa, bagaimana penularannya serta bagaimana menjauhinya dan seterusnya. Modal peningkatan pengetahuan

12 I ketut Putra Julatra, "HIV AIDS Tidak Hanya Menyangkut Masalah Medis, Tetapi Juga Masalah Sosial," Kompasiana, https://www.kompasiana.com/ikpj/54ffb18aa33311566350f970/hivaids-tidak-hanya-menyangkutmasalah-medis-tetapi-juga-masalah-sosial.

13 Zainul Ahwan, "Kampanye Pengurangan Stigma Dan Diskrimisasi Pada ODHA Di Kalangan Warga Nahdlatul Ulama’ NU Bangil Pasuruan,” Jurnal Kebangsaan 4, no. 1 (2014).

Volume 2, Number 2, November 2018 | 147

Penguatan Peran Faith Based Organizations (FBO) Dalam Pencegahan dan Penanggulangan HIV dan AIDS Melalui Peran Aktif Young Relegiuos Leader di Tretes Prigen Pasuruan 


\section{ENGAGEMENT}

Jurnal Pengabdian Kepada Masyarakat

ISSN : 2579-8375 (Print)

ISSN : 2579-8391 (Online)

secara medis ini tentunya akan menjadi kekuatan/langkah awal bagi aktifis muda FBO di Kec, Prigen untuk turut serta melakukan pencegahan HIV dan AIDS di Kec. Prigen Khusunya dan Kabupaten Pasuruan pada umumnya.

Disisi lain, dalam pencegahan HIV dan AIDS tidaklah cukup berhasil hanya dengan melalui penguasaan pengetahuan HIV dalam tinjaun medis saja namun juga perlu memiliki pemahaman yang komprehensip tentang HIV dalam tinjaun agama. Isu HIV memang tidak bisa dilepaskan dari persoalan sosial dan agama mengingat salah satu cara penularan HIV juga ditimbulkan melalui hubungan sex berganti-ganti pasangan (perzinahan) dan narkoba. Data tahun 2017 menunjukkan bahwa penularan HIV terbanyak di Kabupaten Pasuruan didominasi melalui hubungan heteroseksual dengan total 845 kasus dan penularan narkoba jarum suntik sejumlah 155 kasus. ${ }^{14}$

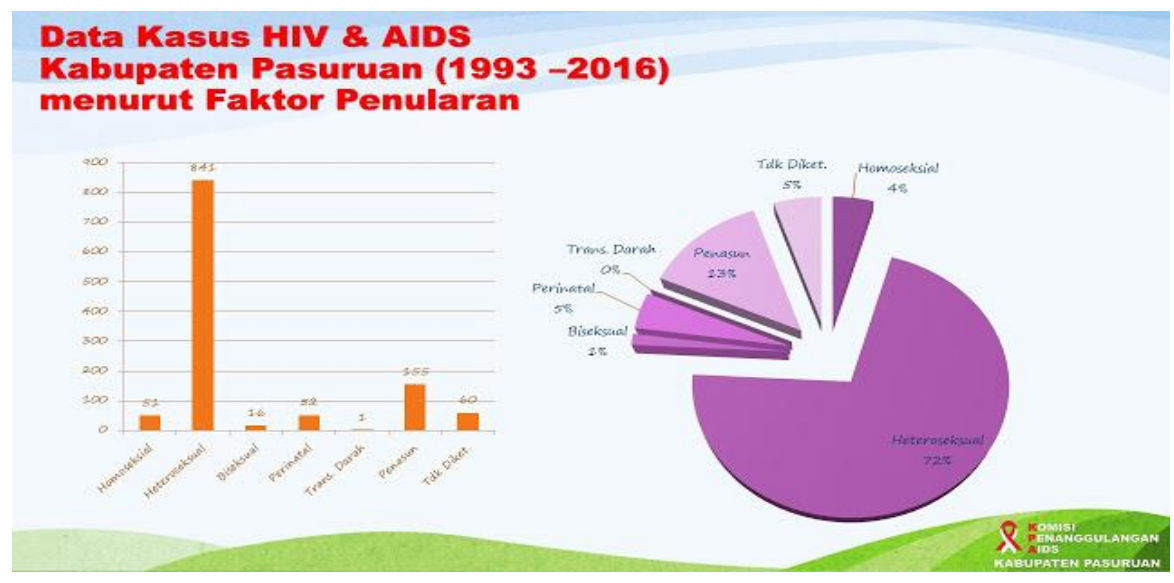

Gambar 5. Data HIV menurut penularan

Persoalan memahami penularan HIV melalui hubungan seksual seringkali meimbulkan justifikasi masyarakat yang kurang tepat bahwa penderita HIV semata-mata hasil dari tindakan yang dilarang agama dan penyakit kutukan Tuhan, padahal faktanya penderita HIV juga banyak yang diderita oleh anak-anak balita serta ibu rumah tangga yang tertular dari suaminya.

Dalam ranah penularan HIV ini, pada saat awal program dilaksanakan memang masih banyak para aktivis pemuda FBO yang beranggapan bahwa persoalan HIV dan AIDS hanya menimpa pada mereka yang melakukan perbuatan yang telah dilarang oleh agama dan asumsi yang berkembang ini 100\% tidaklah benar. Memang dalam konteks penularan HIV melalui hubungan seksual telah diperingatkan secara jelas didalam Alquran

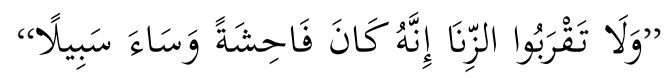

"Dan janganlah kamu mendekati zina; Sesungguhnya zina itu adalah suatu perbuatan yang keji dan suatu jalan yang buruk." (Q.S. Al-Isra: 32).

14 Ibid.

Volume 2, Number 2, November 2018 | 148

Penguatan Peran Faith Based Organizations (FBO) Dalam Pencegahan dan Penanggulangan HIV dan AIDS 
Secara substantif ayat tersebut memberikan peringatan kepada manusia bahwa Islam melarang segala jenis kegiatan yang mengarah kepada perzinaan, termasuk diantaranya seks pranikah, prostitusi, homoseks dan penggunaan narkoba. Akan tetapi dalam konteks penularan HIV ayat tersebut tidak mutlak apabila dijadikan sebagai justifikasi tunggal penularan HIV dari hubungan seksual. Beberapa kasus menunjukkan bahwa banyak perempuan yang sholihah yang tidak pernah melakukan hubungan seksual selain dengan pasangannya juga bisa tertular HIV yang justru diperoleh dari suaminya yang mengudap HIV. Pemahaman inilah kemudian yang membuat perubahan cara pandang para aktif muda FBO dalam melihat persolan HIV bukan lagi HIV semata-mata diperoleh oleh para mereka yang telah melakukan dosa perzinahan. Selain itu, melalui program ini para aktifis muda FBO juga mendapatkan tambahan wawasan dan pengetahuan tentang kajian agama yang relevan dengan persoalan HIV dan AIDS seperti :

a. Bagaimana dalam Alqur'an memberikan penjelasan tentang perilaku homoseksual yang juga merupakan salah satu penyebab HIV dan AIDS.

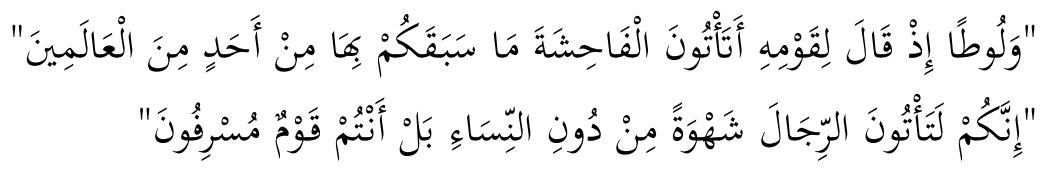

"Dan (kami juga telah mengutus) Luth (kepada kaumnya). (ingatlah) tatkala Dia berkata kepada mereka: "Mengapa kamu mengerjakan perbuatan faabisyah itu, yang belum pernah dikerjakan oleh seorangpun (di dunia ini) sebelummu? Sesunggubnya kamu mendatangi lelaki untuk melepaskan nafsumu (kepada mereka), bukan kepada wanita, malah kamu ini adalah kaum yang melampaui batas." (Q.S. al-A'raf: 80-81). ${ }^{15}$

b. Selain persoalan hubungan seksualitas, persoalan minuman keras/narkoba berjenis jarum suntik juga menjadi salah satu cara yang sangat efektif dalam menularkan HIV.

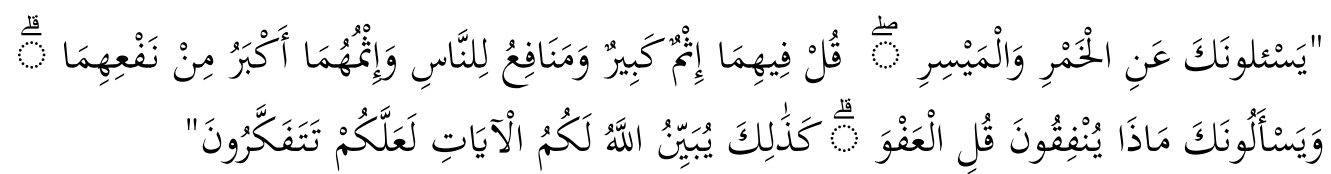

"Mereka bertanya kepadamu tentang khamar dan judi. Katakanlah: "Pada keduanya terdapat dosa yang besar dan beberapa manfaat bagi manusia, tetapi dosa keduanya lebih besar dari manfaatnya". Dan mereka bertanya kepadamu apa yang mereka nafkabkan. Katakanlah: "Yang lebih dari keperluan". Demikianlah Allah menerangkan ayat-ayat-Nya kepadamu supaya kamu berfikir," (QS. Al-Baqarah $: 219)^{16}$

${ }^{15}$ Disalin dari “Al A'raf 80-81: Allah Sebut LGBT Perbuatan Fahisyah, Kaum Yang Melampaui Batas,” https://islamislami.com/2017/12/27/al-araf-80-81-allah-sebut-lgbt-perbuata-fahisyah-kaum-yang-melampauibatas/.

${ }^{16}$ Disalin dari : "Isi Kandungan Al-Qur'an Surat Al-Baqarah Ayat 219."

Volume 2, Number 2, November 2018| 149

Penguatan Peran Faith Based Organizations (FBO) Dalam Pencegahan dan Penanggulangan HIV dan AIDS 
c. Mendorong perubahan masyarakat menuju tatanan ketahanan keluarga sakinah.

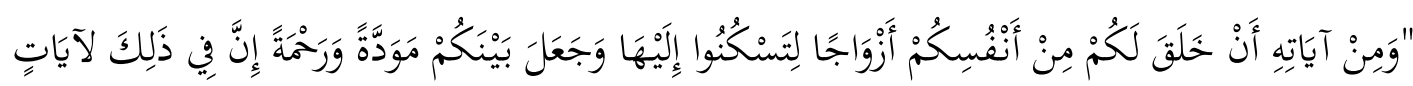

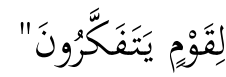

"Dan di antara tanda-tanda kekuasaan-Nya ialab Dia menciptakan untukmu isteri-isteri dari jenismu sendiri, supaya kamu cenderung dan merasa tenteram kepadanya, dan dijadikan-Nya diantaramu rasa kasib dan sayang. (Q.S. ar-Rum: 21)

d. Bersikap kepada Orang dengan HIV/AIDS (ODHA):

1) Memberikan tuntutan rohani (bertobat) agar mereka yakin bahwa tobatnya diterima

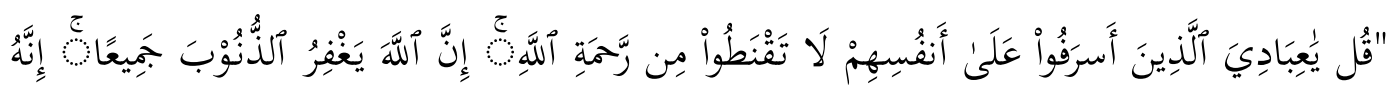

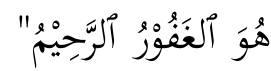

"Katakanlah: "Hai hamba-hamba-Ku yang melampani batas terhadap diri mereka sendiri, janganlah kamu berputus asa dari rabmat Allah. Sesunggubnya Allah mengampuni dosa-dosa semuanya. (Q.S. az-Zumar: 53)

2) Menghindari sikap stigma dan diskriminasi

Stigma dan diskriminasi kepada ODHA tidak akan menyelesaikan permasalahan. Bahkan akan menimbulkan efek psikologi yang berat tentang bagaimana ODHA melihat diri mereka sendiri. Hal ini bisa mendorong, dalam beberapa kasus, terjadinya depresi, kurangnya penghargaan diri, dan keputusasaan.

3) Mendampingi dan memberi dukungan kepada ODHA yang menjelang ajal, agar selalu berzikir, berdoa dan tetap istiqamah dalam keimanannya hingga akhir hayatnya.

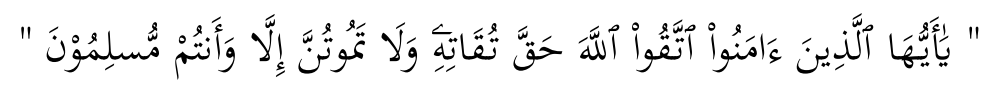

"Hai orang-orang yang beriman, bertakwalah kepada Allah sebenar-benar takwa kepada-Nya; dan janganlah sekali-kali kamu mati melainkan dalam keadaan beragama Islam.” (Q.S. Ali Imran: 102)

Penguasaan persoalan HIV dalam tinjuan agama dengan dalil-dalil yang telah dibahas dalam pelatihan capacity building untuk tokoh muda FBO menjadi pelengkap pengetahuan HIV dalam tinjauan medis. Penyampaian pesan-pesan agama dalam konteks pencegahan HIV dan AIDS akan menjadi sangat efektif apabila dilakukan oleh para pemuka agama. Mengingat pemuka agama merupakan sosok panutan (rule models) yang mempunyai kredibilitas dan integritas yang bisa diikuti anggota / jama'ahnya bahkan pada masyarakat secara luas. Melihat hal itu, peranan dan posisi FBO sebagai ujung tombak pencegahan HIV dan AIDS di kawasan Tretes Prigen Pasuruan menjadi sangat tepat mengingat masyarakat Pasuruan pada umumnya memiliki budaya paternalistik yang cukup tinggi. Keterlibatan aktifis muda FBO akan menjadi 


\section{ENGAGEMENT}

Jurnal Pengabdian Kepada Masyarakat

ISSN : 2579-8375 (Print)

ISSN : 2579-8391 (Online)

opinion leader yang akan mampu merubah paradigma, sikap den perilaku anggota/masyarakat secara umum dalam mamandang persoalan HIV dan AIDS di Kabupaten Pasuruan.

\section{Sinergi Kemitraan dalam pencegahan dan penanggulangan HIV \& AIDS}

Melihat tingginya kasus HIV dan AIDS serta narkoba di Kabupaten Pasuruan maka upaya berbagai pihak baik itu pemerintah, NGO lokal, FBO, lembaga pendidikan beserta semua elemen masyarakat bersama-sama melakukan pencegahan dan penanggulangan terhadap penyebaran HIV dan AIDS di Kabupaten Pasuruan. Kesadaran akan ancaman bahaya HIV dan AIDS di Kabupaten Pasuruan yang semakin mengkhawatirkan inilah yang mampu menjadikan pola sinergi yang apik anatara semua elemen masyarakat secara bersama-sama melakukan proteksi pada area intervensi masing-masing. Peranan masing-masing pihak dapat dilihat dari program dan fokus intervensi yang dilakukan. Misalnya, tim Universitas Yudharta Pasuruan memfokuskan pada kelompok resiko rendah seperti remaja berbasis agama dan pelajar di Kec. Prigen. Yayasan Paramitra fokus pada isu pengurangan dampak buruk dengan berkonsentrasi pada daerah prostitusi di Tretes dan Prigen dengan target intervensi pada komunitas pekerja seks dengan kampanye menggunakan kondom. Dalam melakukan aktivitas, Paramitra bekerjasama dengan USAID. Studio Bangsa berfokus pada isu komunitas penasun di Lapas. Studio Bangsa intervensi sejak tahun 2004 mendapatkan dana dari Kedutaan Finlandia di Jakarta melalui LCF. WAMARAPA fokus pada isu komunitas trans gender/waria di Pasuruan. WAMARAPA mendapatkan dana dari FHI (Family Health International). Komisi Penanggulangan AIDS (KPA) merupakan representasi lembaga pemerintah yang mempunyai tugas khusus berkonsentrasi pada permasalahan HIV dan AIDS. KPA menjadi lembaga yang berfungsi mengkoordinasikan semua mitra pemerintah dalam melakukan pencegahan HIV, memberikan data dan informasi pada semua pihak yang berkepentingan, memberikan layanan pengobatan, perawatan dan dukungan bagi pengidap HIV dan AIDS, memetakan endemi HIV dan AIDS serta memberikan penyuluhan HIV dan melakukan pemberdayaan masyarakat.

\section{Kesimpulan}

Persoalan HIV dan AIDS merupakan persoalan yang serius dan kompleks mengingat HIV bukan hanya menyangkut persoalan medis/kesehatan saja namun juga menyangkut persoalan sosial dan agama. Dalam konteks penularan HIV dan AIDS masuk dalam ranah medis/kesehatan namun dalam konteks stigma dan diskriminasi mencakup persolan sosial dan agama. Melalui Pendampingan masyarakat ini telah mampu meningkatkan kesadaran dan kepedulian aktifis muda 


\section{ENGAGEMENT}

Jurnal Pengabdian Kepada Masyarakat

ISSN : 2579-8375 (Print)

ISSN : 2579-8391 (Online)
This work is licensed under a Creative Commons Attribution-ShareAlike 4.0 International License. CC BY SA

FBO atas persoalan HIV yang terjadi di Kec. Prigen. Selain itu, program ini juga telah memberikan peningkatan pengetahuan dan skill pada para tokoh/aktivis muda FBO baik itu berupa peningkatan pengetahuan tentang HIV baik dalam kajian medis maupun agama, penguasaan teknik komunikasi dalam kampanye bahaya HIV dan AIDS, pemanfaatan teknologi dalam kampanye melalui video blog (Blog). Selain itu, dalam rangka mendukung kesuksesan kegiatan pencegahan HIV yang akan dilakukan FBO di masing-masing level juga dibekali dengan modul pencegahan HIV dan AIDS serta penguatan jejaring antar stakeholder dalam pencegahan HIV dan AIDS di Kabupaten Pasuruan

Tidak bisa dipungkiri, keterlibatan para tokoh/aktivis pemuda agama dalam persoalan ini mempunyai posisi strategis, mengingat para aktivis pemuda agama mempunyai kredibilitas dan legitimasi yang kuat pada anggotanya/masyarakat pada umumnya di Kab, Pasuruan dimana budaya patronase cukup tinggi sehingga upaya kampanye pencegahan HIV dan AIDS yang dilakukan oleh para tokoh muda agama mampu mengubah cara pandang, pola pikir dan sikap serta perilaku anggota/jama'ahnya serta masyarakat dalam menyikapi persoalan HIV yang sekarang semakin mengkhawatirkan di Kabupaten Pasuruan. Stigma dan diskriminasi dari pandangan agama yang kurang tepat akan dapat diminimalisir sehingga upaya pencegahan HIV dan AIDS bisa berjalan dengan baik. 


\section{Daftar Referensi}

Afandi, Agus, Mohammad Hadi Sucipto, and Abdul Muhid. Modul Participatory Action Research (PAR) Untuk Pengorganisasian Masyarakat (Community Organizing). Lembaga Penelitian dan Pengabdian kepada Masyarakat, UIN Sunan Ampel Surabaya, 2016.

Ahwan, Zainul. "Kampanye Pengurangan Stigma Dan Diskrimisasi Pada ODHA Di Kalangan Warga Nahdlatul Ulama’ NU Bangil Pasuruan.” Jurnal Kebangsaan 4, no. 1 (2014).

Bupati Pasuruan. Peraturan Daerah Kabupaten Pasuruan Nomor 4 Tabun 2010 Tentang Tentang Penanggulangan HIV Dan AIDS. Indonesia, 2010.

Julatra, I ketut Putra. "HIV AIDS Tidak Hanya Menyangkut Masalah Medis, Tetapi Juga Masalah Sosial." Kompasiana. https://www.kompasiana.com/ikpj/54ffb18aa33311566350f970/hivaids-tidak-hanyamenyangkut-masalah-medis-tetapi-juga-masalah-sosial.

Komisi Penanggulangan AIDS [KPA] Kabupaten Pasuruan. "Data Kasus HIV Dan AIDS Di Kabupaten Pasuruan.” Last modified 2014. http://kpakabpasuruan.blogspot.com/p/datakasus-hiv-aids.html.

Nurachmah, Elly. "Faktor Pencegahan Hiv/Aids Akibat Perilaku Berisiko Tertular Pada Siswa SLTP.” Makara Seri Kesehatan 13, no. 2 (2009): 63-68.

Octavianty, Lenny, Atikah Rahayu, Dian Rosadi, and Fauzie Rahman. "Pengetahuan, Sikap Dan Pencegahan HIV/AIDS Pada Ibu Rumah Tangga." Jurnal kesehatan masyarakat 11, no. 1 (2015): 53-58.

Purnama, Dadang, and W Witdiawati. "Literasi Penyakit HIV-AIDS Pada Siswa Madrasah Tsanawiah Negeri 1 Garut.” Media Karya Kesehatan 1, no. 1 (2018).

Sudikno, Sudikno, Bona Simanungkalit, and Siswanto Siswanto. "Pengetahuan HIV Dan AIDS Pada Remaja Di Indonesia (Analisis Data Riskesdas 2010)." Jurnal Kesehatan Reproduksi 1, no. 3 Agt (2011): 145-154.

Wicaksono, Wazir, and Taryono Darusman. Pengalaman Belajar Praktek Pengorganisasian Masyarakat Di Simpul Belajar. Bogor: Yayasan Putera, 2001.

"Al A'raf 80-81: Allah Sebut LGBT Perbuatan Fahisyah, Kaum Yang Melampaui Batas." https://islamislami.com/2017/12/27/al-araf-80-81-allah-sebut-lgbt-perbuata-fahisyahkaum-yang-melampaui-batas/.

"Data Kecamatan Prigen Kabupaten Pasuruan." WIKIPEDLA. http://id.wikipedia.org/wiki/Prigen,_Pasuruan.

"Empat PSK Tretes Kembali Ditemukan Positif HIV.” News.Detik.Com. Last modified 2017. https://news.detik.com/berita-jawa-timur/d-3503867/empat-psk-tretes-kembaliditemukan-positif-hivaid.

"Isi Kandungan Al-Qur'an Surat Al-Baqarah Ayat 219." 